\title{
Effectiveness evaluation of alternative sanitizers in microbiological quality of strawberry (Fragaria ananassa Duch Var. Oso Grande) after artificial contamination by Escherichia coli
}

\author{
Renan Gomes BASTOS ${ }^{1}$ (D), Josidel Conceição OLIVER ${ }^{1}$, Jaqueline de Lima GERMANO, \\ Gislene Regina FERNANDES 2 , Sandra Maria Oliveira Morais VEIGA ${ }^{1 \star}$
}

\begin{abstract}
Washing and sanitization are considered particularly critical steps for the microbiological quality of fruits. At this stage, it is important to select the sanitizer which must have microbiological effectiveness. In the literature, there is a great interest on alternative sanitizers for microbiological quality control of food. This study aimed at verifying the effectiveness of sodium hypochlorite, ozone, ultrasound and citric acid as well as associations of ultrasound to the other techniques mentioned above in the microbiological quality control of strawberries cv. Oso Grande. In these trials, the fruits were initially subjected to artificial contamination by a strain of Escherichia coli ATCC 25922 and thereafter part of them was reserved as control samples; the remainder was submitted to different kinds of sanitization treatment. Then, some microbiological analyses of coliforms counts at $45^{\circ} \mathrm{C}$ were performed with those present in the control samples and in the post-sanitization samples, through the enzymatic technique of chromogenic substrate. The three most efficient treatments for maintaining the microbiological quality of the fruit were $2 \%$ citric acid, $2 \%$ citric acid associated with ultrasound and ozone.
\end{abstract}

Keywords: sanitization; strawberries; citric acid; ultrasound; ozone.

Practical Application: This work could provide subsidies for the use of alternative sanitizers, for example, in minimum fruit processing methodologies in micro and large industries.

\section{Introduction}

Chlorine and its derivatives have been known as the most commonly used substances for sanitizing fruits. However, studies have shown that their applicability may lead to some toxic by-products production (Nunes et al., 2010). Thus, it gets more clear that the most powerful and effective sanitizers must be explored. Therefore, food researchers have been increasingly seeking alternative methods for cutting off pathogenic and deteriorating food-borne bacteria which could harm neither human beings nor the environment (Lin et al., 2010).

The use of ozone as a sanitizer is related to its high biocidal effectiveness, wide antimicrobial spectrum and absence of health-threatening residues. Its effectiveness depends not only on the applied quantity, but also on the remaining quantity in the medium. In order to ensure an effective disinfection, it is required monitoring the availability of the product during the treatment, so that the initial and residual concentrations could be monitored (González-Aguilar et al., 2010; Santos \& Roza, 2010). In addition, when ozone is used in post-harvest treatments, its high oxidation power can promote undesirable changes in food quality. For this reason, an optimal optimization of the food treatment conditions must be done (Souza et al., 2018).

Besides being a very recent practice, the use of ultrasound in food preservation requires more in-depth studies for being performed, once in spite of inactivating particular species of microorganisms, it can lead to some adverse effects on the final quality of the product (Nascimento et al., 2008; São José et al., 2014). Ultrasound technology has been widely studied for the processing of food products with the aim of avoiding the negative effects of conventional heat treatment, especially the loss of vitamins and some minerals (Guimarães et al., 2018).

In the group of alternative sanitizers, it also arises the so-called "green" or ecologically correct sanitizers, in which the citric acid is the most studied one at the moment. It can be used alone or associated with conventional sanitizers and other alternative technologies, therefore it can be shown as an excellent candidate for using on fruits such as strawberries (Lin et al., 2010).

Strawberry (Fragaria ananassa Duch.) is considered not only as one of the healthiest fruits but also as one of the most consumed fruits by the current generation, due to its benefits and functional properties. As it is a highly perishable fruit, consequently it is quite likely to undergo microbiological contaminations from external environment (Antunes et al., 2006; Cocco et al., 2016). In order to do the microbiological control of this fruit, it is often performed its initial contamination decrease by using substances with high sanitizing capacity such

${ }^{1}$ Departamento de Alimentos e Medicamentos, Faculdade de Ciências Farmacêuticas, Universidade Federal de Alfenas - UNIFAL, Alfenas, MG, Brasil

${ }^{2}$ Faculdade de Nutrição, Universidade Federal de Alfenas - UNIFAL, Alfenas, MG, Brasil

${ }^{*}$ Corresponding author: smveiga@gmail.com 
as sodium hypochlorite, organic acids and irradiations (São José \& Vanetti, 2015).

Based on those considerations, the present study aimed at assessing the effectiveness of alternative sanitizers on strawberry, through microbiological quality trials, after artificial contamination of the fruit with a strain of Escherichia coli ATCC 25922. Thus, this work will be able to provide subsidies for using alternative sanitizers, for example, in minimum fruit processing methodologies within micro and large industries.

\section{Materials and methods}

\subsection{Acquisition of samples}

Strawberries of the variety Oso Grande were purchased from the local commerce of the city of Alfenas-MG, which received the strawberries directly from producers from the city of Pouso Alegre-MG (S22 $\left.21^{\prime} 04.2^{\prime \prime}, \mathrm{W} 45^{\circ} 54^{\prime} 00.3^{\prime \prime}\right)$. The newly collected samples were transported in polyethylene boxes which were kept in an isothermal container until they got to the Federal University of Alfenas, UNIFAL-MG. In order to study the influence of alternative sanitizers on microbial quality (native microbiota) of the fruit, the experiment was performed with $6.0 \mathrm{~kg}$ of strawberries.

\subsection{Artificial contamination of strawberries}

Initially, strawberry samples were subjected to an artificial contamination procedure by the strain of Escherichia coli ATCC 25922, according to the methodology described by Moraes et al. (2008). In the contamination procedure, the culture of E. coli in BHI agar was used in the logarithmic phase of growth and then from it, a suspension was performed in $9.0 \mathrm{~mL}$ sterile saline solution, in the same turbidity as the tube 10 from the McFarland scale. All strawberry samples were placed in sterile 5.0 L containers along with $4.0 \mathrm{~L}$ of sterile saline solution, $4.0 \mathrm{~mL}$ of bacterial suspension and $4.0 \mathrm{~mL}$ of UHT whole milk in order to increase bacterial adhesion on the surface of the fruit.

To check bacterial adhesion to the fruit, within comparative terms, an artificial contamination was separatedly carried out using $1.0 \mathrm{~kg}$ of strawberries with $2.0 \mathrm{~mL}$ of bacterial suspension and $2.0 \mathrm{~mL}$ of UHT skim milk in a $2.0 \mathrm{~L}$ sterile container.

Then the artificially contaminated samples were drained and $50 \mathrm{~g}$ of each individual sample were weighed, transferred separately to a flask containing $450 \mathrm{~mL}$ of sterile saline corresponding to the negative control group and eventually reserved for microbiological analyses. The remaining strawberries were subjected to sanification processes by each one of the sanitizers and/or association, for later microbiological analysis.

\subsection{Sanitization of strawberries}

All the sanitizers and associations among them, used in the present work, were based on their industrial importance.

The sanitizers chosen were sodium hypochlorite $(\mathrm{SH})$ (50 and $100 \mathrm{ppm}$ ), ozone (OZ), ultrasound (US) and citric acid (CA) (1\% and $2 \%$ ), as well as the associations US + SH 50 ppm, US + SH 100 ppm, US + OZ, US + 1\% CA and US + CA 2\%.
As standard reference treatment, $\mathrm{SH}$ solutions at 50 and $100 \mathrm{ppm}$ were used.

Sodium hypochlorite was used at 50ppm and 100ppm concentrations in solutions prepared according to the methodology proposed by Sun et al. (2012). For ozone production, the Brazilian Ozone generator, model BRO3- $3^{\circledR}$, was operated with 3.0 L flow of medical oxygen per minute and $0.3 \mathrm{kgF} / \mathrm{cm}^{2}$ of pressure. Rubber tubes were adapted to the input and output of the generator. To that coupled to its output, a sintered glass diffuser was inserted into the tube for the purpose of producing fine bubbles. For the ozone treatment, strawberries were placed into a $2.0 \mathrm{~L}$ beaker along with $1.2 \mathrm{~L}$ of distilled water, once the diffuser was inserted into the beaker to produce the necessary fine bubbles. Initial and residual concentrations of ozone, under the different treatments in which it was used, were determined by the indirect iodometry method (Santos \& Roza, 2010). Ultrasound was applied at $40 \mathrm{KHz}$ frequency, available in the Sanders ${ }^{\circledR}$ DF6000014 ultrasonic vessel, according to the methodology proposed by Garcia-Noguera et al. (2010). Citric acid was used at concentrations of $1 \%$ and $2 \%$, in which solutions were prepared from the product in its purified form, according to the methodology described by Allende et al. (2009).

In treatments involving only the use of ultrasound, distilled water was used as immersion medium for the strawberry samples. In treatments which ultrasound was associated with sodium hypochlorite and citric acid, 4.0 L of solution of each sanitizers were used under the two proposed concentrations. In the treatment which ultrasound was associated with ozone, the diffuser was coupled to the ultrasound and in order to promote the dispersion of the fine bubbles throughout the ultrasonic vessel, a manual stirrer was used.

In each treatment, the initial $\mathrm{pH}$ of the immersion solution of the strawberries and the temperatures before and after sanitizing. All samples were kept in contact with the sanitizer for 15 minutes and the analyses were performed in triplicate.

\subsection{Sample preparation for microbiological analysis}

After the sanitizations, the strawberries were centrifuged within a centrifuge appropriate for food, and then $50 \mathrm{~g}$ of each treatment were weighed and separately transferred into flasks containing $450 \mathrm{~mL}$ of $0.85 \%$ sterile saline. Each flask was homogenised on $\mathrm{IKA}^{\circledR}$ KS 260 Basic shaker, for 5 minutes, at $300 \mathrm{rpm}, 1: 10$ dilution. From this, 1:100, 1:1000 and 1:10000 dilutions were made in $0.85 \%$ sterile saline.

\subsection{Total coliform count at $45^{\circ} \mathrm{C}$}

For coliforms counts at $45^{\circ} \mathrm{C}$ found in the negative control and in the post-sanitization samples, the enzymatic technique of the chromogenic substrate (Simplate ${ }^{\circledR}$ kit, BioControl AOAC ${ }^{\circledR}$ Official Methods 2005.03 brand) was used and the analyses were carried out according to instructions of the manufacturer. The plates were then incubated in a regulated laboratory stove at $37^{\circ} \mathrm{C}$ for 24 to 28 hours. From the number of positive wells with fluorescence emission, Escherichia coli counts were performed by using an ultraviolet light chamber $(365 \mathrm{~nm})$. The most likely number per gram of sample (NMP/g) was calculated by using 
the table provided by the kit manufacturer. All analyses were done in triplicate.

\subsection{Statistical analysis}

Statistical analysis were performed using Sisvar ${ }^{\circledR}$ software Version 5.3/DEX-UFLA (Copyright, 1999-2010), where the analysis of variance (ANOVA) could be performed and followed by Scott \& Knott test, at a significance level of 5\% ( $\mathrm{p}<0.05)$.

\section{Results and discussion}

The average temperatures and the $\mathrm{pH}$ values obtained from the different applied treatments are presented in Table 1. The importance of determining these parameters is due to the fact that extrinsic factors favor the microbial growth, depending on the range in which they are found and it ensures the reliability of the results (Lin et al., 2010).

It could be observed that, in control samples, there was a higher percentage adhesion of the bacteria at hand, when whole milk was used. The whole milk presented an average percentage of $94.05 \%$, whereas skimmed milk presented an average percentage of adhesion of the bacteria of $86.90 \%$ (Table 2).

Among all treatments, $2 \%$ citric acid and its association with ultrasound, as well as ozone, were shown as the three most effective whose microbial reductions were on average $100 \%$ for each one (Table 3). Once compared to the reference treatments (50 and $100 \mathrm{ppm}$ sodium hypochlorite), only $100 \mathrm{ppm}$ sodium hypochlorite presented results with $100 \%$ microbial reduction.

Among all treatments and compared to HS at $100 \mathrm{ppm}$ (reference), $2 \%$ citric acid (alone or associated with ultrasound)

Table 1. Average temperatures and $\mathrm{pH}$ values of treatments applied to strawberries.

\begin{tabular}{lcc}
\hline \multicolumn{1}{r}{ Type of treatment } & Average temperature $\left({ }^{\circ} C\right)$ & $\mathrm{pH}$ \\
\hline SH 50 ppm & $14.80 \pm 0.97^{\mathrm{a}}$ & $7.21 \pm 0.12^{\mathrm{c}}$ \\
SH $50 \mathrm{ppm}+$ US & $13.83 \pm 1.18^{\mathrm{a}}$ & $7.15 \pm 0.14^{\mathrm{c}}$ \\
SH $100 \mathrm{ppm}$ & $15.98 \pm 1.03^{\mathrm{a}}$ & $7.13 \pm 0.06^{\mathrm{c}}$ \\
SH $100 \mathrm{ppm}+\mathrm{US}$ & $15.83 \pm 0.76^{\mathrm{a}}$ & $7.15 \pm 0.23^{\mathrm{c}}$ \\
CA $1 \%$ & $14.04 \pm 0.88^{\mathrm{a}}$ & $2.26 \pm 0.14^{\mathrm{a}}$ \\
CA $1 \%+$ US & $15.67 \pm 1.31^{\mathrm{a}}$ & $2.32 \pm 0.32^{\mathrm{a}}$ \\
AC $2 \%$ & $16.10 \pm 1.15^{\mathrm{a}}$ & $2.21 \pm 0.20^{\mathrm{a}}$ \\
CA 2\%+ US & $16.00 \pm 0.48^{\mathrm{a}}$ & $2.23 \pm 0.16^{\mathrm{a}}$ \\
OZ & $16.35 \pm 1.15^{\mathrm{a}}$ & $6.15 \pm 0.12^{\mathrm{b}}$ \\
OZ + US & $14.15 \pm 0.98^{\mathrm{a}}$ & $6.29 \pm 0.08^{\mathrm{b}}$ \\
US & $13.40 \pm 0.65^{\mathrm{a}}$ & $6.35 \pm 0.10^{\mathrm{b}}$ \\
\hline
\end{tabular}

The results represent the mean \pm standard deviation of each group, with the value of $n=3$. The results of each test were separately analyzed. Means with different letters, in the same column, are statistically different by Scott and Knott test, being $\mathrm{p}<0.05 . \mathrm{SH}=$ sodium hypochlorite; US = ultrasound; $\mathrm{CA}=$ citric acid; $\mathrm{OZ}=$ ozone.

Table 2. Percentage of adhesion of E. coli artificially inoculated in strawberries according to the type of milk used.

\begin{tabular}{lcc}
\hline \multicolumn{1}{c}{ Control samples } & MLNM/mL & \% adhesion \\
\hline Whole milk & 60120 & $94.05 \%$ \\
Skimmed milk & 55550 & $86.90 \%$ \\
\hline
\end{tabular}

MLNM = most likely number of microorganisms. and ozone (alone) were shown as the most effective, whose microbial reductions was on average $100 \%$ for each one.

Considering that the ideal efficacy of a sanitizer should be higher than 99.99\% (Ölmez \& Akbas, 2009), it can then be considered that these results are within the desirable microbiological parameters.

The residual ozone concentration obtained in the treatments was $2.96 \mathrm{ppm}$, determined by the indirect iodometric method, specified in Santos \& Roza (2010).

The results from sanitizing with ozone of the present study were similar to those determined by Ponce et al. (2010), whose researchers also observed $100 \%$ microbial reduction of E. coli in strawberries exposed to $\mathrm{O}_{3}$ for 30 minutes and 60 minutes, respectively.

There are few reports in the literature on the ozonation of strawberries, which are less restrict to the control of filamentous fungi and yeasts, Salmonella sp. and aerobic mesophilic bacteria in these fruits, after the sanitization. Bialka et al. (2008) verified that the use of gaseous ozone caused a reduction of 2.06 and $2.96 \mathrm{log}$ cycles in Salmonella sp. and E. coli O157:H7 population, respectively, in strawberries occasionally contaminated with these pathogens.

The importance of the use of ozone in the maintenance of the microbial quality of the fruits is in the fact that it can decompose the ethylene and destroy microorganisms by progressive oxidation of the phospholipids and molecules of proteins in the cellular membrane. Thus, the permeability of cell membranes is increased, allowing the leakage of cellular content and, eventually, leading to the death of microorganisms (Han et al., 2017).

The results obtained by $1 \%$ citric acid were also higher than those obtained by Carvalho \& Lima (2002), whose study evaluated the microbial reduction profile of kiwi fruit contaminated with E. coli and subjected to treatment with this sanitizer (isolated and associated with ultrasound) finding a result equivalent to $92.5 \%$.

The $2 \%$ citric acid presented a result of $100 \%$ microbial reduction, however, among all treatments, it was the one that

Table 3. Reduction percentage of artificially inoculated E. coli in strawberries due to different sanitizers employed.

\begin{tabular}{lcc}
\hline \multicolumn{1}{c}{ Treatment } & Average MLNM/mL & Average \% reduction \\
\hline SH 50 ppm & $67.00 \pm 1.15^{\mathrm{b}}$ & $99.89 \%$ \\
SH 50 ppm + US & $133.00 \pm 2.30^{\mathrm{c}}$ & $99.78 \%$ \\
SH 100 ppm & $0.00 \pm 0.00^{\mathrm{a}}$ & $100 \%$ \\
SH 100 ppm + US & $133.00 \pm 2.30^{\mathrm{c}}$ & $99.78 \%$ \\
CA 1\% & $133.00 \pm 2.30^{\mathrm{c}}$ & $99.78 \%$ \\
CA 1\% + US & $67.00 \pm 1.15^{\mathrm{b}}$ & $99.89 \%$ \\
CA 2\% & $0.00 \pm 0.00^{\mathrm{a}}$ & $100 \%$ \\
CA 2\% + US & $0.00 \pm 0.00^{\mathrm{a}}$ & $100 \%$ \\
OZ & $0.00 \pm 0.00^{\mathrm{a}}$ & $100 \%$ \\
OZ + US & $67.00 \pm 1.15^{\mathrm{b}}$ & $99.89 \%$ \\
US & $467.00 \pm 1.54^{\mathrm{d}}$ & $99.22 \%$ \\
\hline
\end{tabular}

The results represent the mean \pm standard deviation of each group, with the value of $n=3$. The results of each test were separately analyzed. Means with different letters, in the same column, are statistically different by Scott and Knott test, being $\mathrm{p}<0.05 . \mathrm{SH}=$ sodium hypochlorite; US = ultrasound; $\mathrm{CA}=$ citric acid; $\mathrm{OZ}=$ ozone; $\mathrm{MLNM}=$ most likely number of microorganisms. 
most compromised physical attributes of the strawberry, mainly causing the loss of its natural coloration to the sanitizing solution and decreasing the firmness of the fruit. Likewise when this same sanitizer is associated with ultrasound, the percentage of microbial reduction was $100 \%$, but those attributes were slightly altered.

In the study performed by Chagas et al. (2008), researchers also observed that citric acid used under $2 \%$ concentration in sanitizing Regis peaches minimally processed and stored under modified atmosphere also provided changes on sensorial quality of these fruits, such as firmness and increased enzymatic browning and texture. These researchers also concluded that using this acid under this concentration is not very effective for preventing sensorial changes on horticultural products.

The results of the present study were also compared to studies performed by González et al. (2004) and Allende et al. (2009). In the first one, researchers obtained a microbial reduction of $E$. coli $\mathrm{O} 157: \mathrm{H} 7$ bacteria about $94.0 \%$ in the treatments of carrots minimally processed with the association of $4 \%$ citric acid and ultrasound. In the second one, the percentage of microbial reduction was $98.0 \%$ in coriander sanitized by $0.6 \%$ citric acid associated with ultrasound.

In recent years, the use of ultrasound has become innovative and seen as a compelling technology with increasing applications in the food industry due to its promising effects on food processing and preservation. It has unique advantages over other technologies in the food industry, since acoustic waves are generally considered safe, non-toxic from both technological and environmental standpoints. However, ultrasonic irradiation is known to cause mechanical, physical damage and chemical changes in fruits, due to the rapid formation and destruction of cavitation bubbles, which may alter its antimicrobial capacity. Due to this, the technique is usually associated with another sanitization method (Wang et al., 2015).

Among all the treatments performed in the present study, ultrasound was the least effective one, showing $99.22 \%$ as its average percentage of microbial reduction. Nevertheless, the result was superior to the one found by Oliveira et al. (2008) in which the researchers determined $88.0 \%$ as the percentage of $E$. coli reduction in the initial microbiological analysis of minimally processed and ultrasonically sanitized tilapia fillets.

Ultrasound is known for degrading organic matter present in food, forming low molecular weight compounds. Thus, organic substances found naturally in the composition of strawberry could be degraded in compounds with greater ease of assimilation by $E$. coli, which may justify the lower percentage of microbial reduction when this sanitizing agent was used, as it may have occurred a greater dispersion of these microorganisms in the medium. Nascimento et al. (2008) also stated that a decrease in the amount of microorganisms is expected as the course of the ultrasound treatment goes on, thus, a longer sanitization time may be used.

\section{Conclusion}

It can be concluded that the best treatments for strawberries in the microbiological area were $2 \%$ citric acid, $2 \%$ citric acid associated with ultrasound and isolated ozone, once their percentages of microbial reduction were $100 \%$ compared to the reference treatments. Among these three treatments, $2 \%$ citric acid associated with ultrasound and ozone showed the smallest visible changes on physical attributes of the strawberry, representing therefore the best alternatives for sanitizing these fruits.

\section{Acknowledgements}

The authors thank both the Foundation for Research Support of the State of Minas Gerais (FAPEMIG) for financial support and the Federal University of Alfenas (UNIFAL-MG) for making the work available.

\section{References}

Allende, A., McEvoy, J., Tao, Y., \& Luo, Y. (2009). Antimicrobial effect of acidified sodium chlorite, sodium chlorite, sodium hypochlorite, and citric acid on Escherichia coli O157:H7 and natural microflora of fresh-cut cilantro. Food Control, 20(3), 230-234. http://dx.doi. org/10.1016/j.foodcont.2008.05.009.

Antunes, O. T., Calvete, E. O., Rocha, H. C., Nienow, A. A., Mariani, F., \& Wesp, C. L. (2006). Floração, frutificação e maturação de frutos de morangueiro cultivados em ambiente protegido. Horticultura Brasileira, 24(4), 426-430. http://dx.doi.org/10.1590/S010205362006000400006

Bialka, K. L., Demirci, A., \& Puri, V. M. (2008). Modeling the inactivation of Escherichia coli O157:H7 and Salmonella enterica on raspberries and strawberries resulting from exposure to ozone or pulsed UVlight. Journal of Food Engineering, 85(3), 444-449. http://dx.doi. org/10.1016/j.jfoodeng.2007.08.007.

Carvalho, A. V., \& Lima, L. C. O. (2002). Qualidade de kiwis minimamente processados e submetidos a tratamento com ácido ascórbico, ácido cítrico e cloreto de cálcio. Pesquisa Agropecuária Brasileira, 37(5), 679-685. http://dx.doi.org/10.1590/S0100-204X2002000500013.

Chagas, P. C., Shirahige, F. H., Silva, P. P. M., Spoto, M. H. F., Chagas, E. A., \& Pio, R. (2008). Avaliação da qualidade de pêssegos "Regis" minimamente processados. Revista do Centro de Pesquisa e Processamento de Alimentos, 26(2), 179-186. http://dx.doi.org/10.5380/ cep.v26i2.13271.

Cocco, K. L. T., Schmidt, D., Caron, B. O., Souza, V. Q., Fontana, D. C., \& Paula, G. M. (2016). Estimated phyllochron in low tunnel cultivated strawberry cultivars. Ciência Rural, 46(9), 1546-1552. http://dx.doi.org/10.1590/0103-8478cr20150708.

Garcia-Noguera, J., Oliveira, F. I. P., Gallão, M. I., Weller, C. L., Rodrigues, S., \& Fernandes, F. A. N. (2010). Ultrasound-assisted osmotic dehydration of strawberries: effect of pretreatment time and ultrasonic frequency. Drying Technology, 28(1), 294-303. http:// dx.doi.org/10.1080/07373930903530402.

González, R. J., Luo, Y., Ruiz-Cruz, S., \& McEvoy, J. L. (2004). Efficacy of sanitizers to inactivate Escherichia coli O157:H7 on fresh-cut carrot shreds under simulated process water conditions. Journal of Food Protection, 67(11), 2375-2380. http://dx.doi.org/10.4315/0362028X-67.11.2375. PMid:15553615.

González-Aguilar, G. A., Ayala-Zavala, J. F., Olivas, G. I., De la Rosa, L. A., \& Álvarez-Parrilla, E. (2010). Preserving quality of fresh-cut products using safe technologies. Journal of Consumer Protection and Food Safety, 5(1), 65-72. http://dx.doi.org/10.1007/s00003-009-0315-6.

Guimarães, J. T., Silva, E. K., Alvarenga, V. O., Costa, A. L. R., Cunha, R. L., Sant'Ana, A. S., Freitas, M. Q., Meireles, M. A. A., \& Cruz, A. G. (2018). Physicochemical changes and microbial inactivation after high-intensity ultrasound processing of prebiotic whey beverage applying different ultrasonic power levels. Ultrasonics Sonochemistry, 44(1), 251-260. http://dx.doi.org/10.1016/j.ultsonch.2018.02.012. PMid:29680610. 
Han, Q., Gao, H., Chen, H., Fang, X., \& Wu, W. (2017). Precooling and ozone treatments affects postharvest quality of black mulberry (Morus nigra) fruits. Food Chemistry, 221(1), 1947-1953. http:// dx.doi.org/10.1016/j.foodchem.2016.11.152. PMid:27979184.

Lin, C., Sheu, S., Hsu, S., \& Tsai, Y. (2010). Determination of bactericidal efficacy of essential oil extracted from orange peel on the food contact surfaces. Food Control, 21(12), 1710-1715. http://dx.doi. org/10.1016/j.foodcont.2010.06.008.

Moraes, I. V. M., Cenci, S. A., Benedetti, B. C., Mamede, A. M. G. N., Soares, A. G., \& Barboza, H. T. G. (2008). Características físicas e químicas de morango processado minimamente e conservado sob refrigeração e atmosfera controlada. Food Science and Technology, 28(2), 274-281. http://dx.doi.org/10.1590/S0101-20612008000200003.

Nascimento, L. C., Lima, L. C. O., Picolli, R. H., Fiorini, J. E., Duarte, S. M. S., Silva, J. M. S. F., Oliveira, N. M. S., \& Veiga, S. M. O. M. (2008). Ozônio e ultra-som: processos alternativos para o tratamento do café despolpado. Food Science and Technology, 28(2), 282-294. http://dx.doi.org/10.1590/S0101-20612008000200004.

Nunes, E. E., Vilas Boas, E. V. B., Xisto, A. L. R. P., Leme, S. C., \& Botelho, M. C. (2010). Avaliação de diferentes sanificantes na qualidade microbiológica de mandioquinha-salsa minimamente processada. Ciência e Agrotecnologia, 34(4), 990-994. http://dx.doi.org/10.1590/ S1413-70542010000400027.

Oliveira, N. M. S., Oliveira, W. R. M., Nascimento, L. C., Silva, J. M. S. F., Vicente, E., Fiorini, J. E., \& Bressan, M. C. (2008). Avaliação físico-química de filés de tilápia (Oreochromis niloticus) submetidos à sanitização. Food Science and Technology, 28(1), 83-89. http:// dx.doi.org/10.1590/S0101-20612008000100013.

Ölmez, H., \& Akbas, M. Y. (2009). Optimization of ozone treatment of fresh-cut green leaf lettuce. Journal of Food Engineering, 90(4), 487-494. http://dx.doi.org/10.1016/j.jfoodeng.2008.07.026.
Ponce, A. R., Bastiani, M. I. D., Minim, V. P., \& Vanetti, M. C. D. (2010). Características físico-químicas e microbiológicas de morango minimamente processado. Food Science and Technology, 30(1), 113-118. http://dx.doi.org/10.1590/S0101-20612010005000016.

Santos, R. B., \& Roza, C. R. (2010). Aplicação de ozônio em alimentos. Revista Higiene Alimentar, 24(190-191), 88-94.

São José, J. F. B., Andrade, N. J., Ramos, A. M., Vanetti, M. C. D., Stringheta, P. C., \& Chaves, J. B. P. (2014). Decontamination by ultrasound application in fresh fruits and vegetables. Food Control, 45(1), 36-50. http://dx.doi.org/10.1016/j.foodcont.2014.04.015.

São José, J. F. B., \& Vanetti, M. C. D. (2015). Application of ultrasound and chemical sanitizers to watercress, parsley and strawberry: microbiological and physicochemical quality. LebensmittelWissenschaft + Technologie, 63(2), 946-952. http://dx.doi.org/10.1016/j. lwt.2015.04.029.

Souza, L. P., Faroni, L. R. D., Heleno, F. F., Cecon, P. R., Gonçalves, T. D. C., Silva, G. J., \& Prates, L. H. F. (2018). Effects of ozone treatment on postharvest carrot quality. Lebensmittel-Wissenschaft + Technologie, 90(1), 53-60. http://dx.doi.org/10.1016/j.lwt.2017.11.057.

Sun, S. H., Kim, S. J., Kwak, S. J., \& Yoon, K. S. (2012). Efficacy of sodium hypochlorite and acidified sodium chlorite in preventing browning and microbial growth on fresh-cut produce. Preventive Nutrition and Food Science, 17(3), 210-216. http://dx.doi.org/10.3746/ pnf.2012.17.3.210. PMid:24471086.

Wang, W., Ma, X., Zou, M., Jiang, P., Hu, W., Li, J., Zhi, Z., Chen, J., Li, S., Ding, T., Ye, X., \& Liu, D. (2015). Effects of ultrasound on spoilage microorganisms, quality, and antioxidant capacity of postharvest cherry tomatoes. Journal of Food Science, 80(10), C2117-C2126. http://dx.doi.org/10.1111/1750-3841.12955. PMid:26375026. 